\title{
Co-occurring morphologically distinct algae support a diverse associated fauna in the intertidal zone of Araçá Bay, Brazil
}

\author{
Edson A. Vieira ${ }^{1 *}$ (D), Heloísa Romeu Filgueiras ${ }^{1}$, Marília Bueno ${ }^{2}$, Fosca Pedini Pereira Leite ${ }^{2}$ \& \\ Gustavo Muniz Dias ${ }^{1}$ \\ ${ }^{1}$ Universidade Federal do ABC, Centro de Ciências Naturais e Humanas São Bernardo do Campo, SP, Brazil \\ ${ }^{2}$ Universidade Estadual de Campinas, Departamento de Biologia Animal, Campinas, SP, Brazil \\ *Corresponding author: Edson A. Vieira,e-mail: edson.vieira@ufabc.edu.br
}

VIEIRA, E. A., FILGUEIRAS, H.R., BUENO, M., LEITE, F. P.P., DIAS, G. M. Co-occurring morphologically distinct algae support a diverse associated fauna in the intertidal zone of Araçá Bay, Brazil. Biota Neotropica. 18(1): e20170464. http://dx.doi.org/10.1590/1676-0611-BN-2017-0464

\begin{abstract}
Species diversity is regulated by historical, neutral and niche processes, with species tolerance, dispersal and productivity guiding diversity at larger scales, while habitat heterogeneity and biotic interactions acts in smaller scales. In rocky shores, several organisms provide secondary substrates for mobile fauna, with macroalgae being the most abundant and diverse ones. The patchiness promoted by different macroalgae hosts enhances small-scale heterogeneity and may increase and maintain the diversity of the mobile organisms, since there is a close relationship between the associated fauna and its hosts. In this study we selected three morphologically different macroalgae that coexist in the same rocky shore height in the Araçá Bay, an area under the threat of the nearby harbor expansion, and evaluated the fauna associated to each algal host. Even under similar abiotic pressure (same rocky shore height), the associated fauna of each algal host varied in number and composition, revealing a close relationship. The poorly branched foliose Ulva lactuca sustained a lower density of organisms and was dominated by isopods, while the heavily branched turf and Bostrychietum community showed a high density of organisms, with a dominance of peracarid crustaceans and annelids on the turf and more resistant groups, such as bivalves, acaris and terrestrial insects on the Bostrychietum. Previous studies in the Araçá Bay already revealed a large spatial heterogeneity in the processes and sessile organisms distribution, and here we highlight that this heterogeneity can be observed in an even smaller scale, with different algal hosts mediating the turnover of species in a scale of centimeters and meters, resulting in diversity maintenance of the associated fauna. Since the harbor expansion may prevent the occurrence of macroalgae as a result of light limitation by suspended platforms, we may expect not only a decrease in algal cover but also in the total diversity of the associated fauna in the Araçá Bay.
\end{abstract}

Keywords: rocky shore, phytal, peracarids, structural complexity, spatial heterogeneity

\section{Algas co-ocorrentes e morfologicamente distintas suportam uma diversa fauna associada na zona entremarés na Baía do Araçá, Brasil}

Resumo: A diversidade de espécies é regulada por processos históricos, neutros e de nicho, com a tolerância das espécies, dispersão e produtividade do sistema guiando a diversidade em grandes escalas, enquanto a heterogeneidade do habitat e as interações bióticas atuam em escalas menores. Em costões rochosos uma série de organismos funciona como substrato secundário para a fauna móvel, sendo macroalgas o tipo mais abundante e diverso de substrato. O mosaico formado pelas diferentes macroalgas hospedeiras aumenta a heterogeneidade em pequena escala e pode aumentar e manter a diversidade dos organismos móveis, uma vez que existe uma relação próxima entre a fauna associada e seus hospedeiros. Neste estudo nós selecionamos três macroalgas diferentes morfologicamente e que coexistem na mesma altura no costão rochoso na Baía do Araçá, uma área sob a ameaça de expansão do porto que fica nas proximidades, e analisamos a fauna associada a cada alga hospedeira. Mesmo sob pressões abióticas similares (mesma altura no costão rochoso), a fauna associada a cada alga variou em número e composição, revelando de fato uma relação próxima entre fauna e alga. Ulva lactuca, uma alga foliosa com pouca ramificação, apresentou uma baixa densidade de organismos e foi dominada por isópodes, enquanto que o turf e o Bostrychietum, algas altamente ramificadas e mais complexas, apresentaram uma alta densidade de organismos, com uma dominância de crustáceos peracáridos e anelídeos no turf e grupos mais resistentes como bivalves, ácaros e insetos terrestres no Bostrychietum. Estudos anteriores conduzidos na Baía do Araçá já mostraram uma grande heterogeneidade espacial nos processos ecológicos e na distribuição dos 
organismos sésseis, e aqui nós ressaltamos que esta heterogeneidade pode ser observada numa escala ainda menor, com as diferentes algas mediando o turnover de espécies numa escala de centímetros a metros, resultando na manutenção da diversidade da fauna associada. Como a expansão do porto pode impedir a ocorrência das macroalgas devido à limitação de luz que será imposta pelas plataformas flutuantes, nós podemos esperar não apenas uma diminuição da cobertura de macroalgas mas também da diversidade total da fauna associada na Baía do Araçá.

Palavras-chave: costão rochoso, fital, peracáridos, complexidade estrutural, heterogeneidade espacial

\section{Introduction}

The diversity of species in an ecosystem is determined by historical, neutral and niche processes acting on both large and small spatial scales, which combined will determine the biodiversity patterns in a global scale (Ricklefs 1987, Huston 1999, Shurin \& Allen 2001, Navarrete et al. 2005). While in large-scale, diversity is usually regulated by species tolerances, dispersal and productivity (Menge \& Olson 1990, Whittaker et al. 2001, Hawkins et al. 2004), in small-scale, habitat heterogeneity and biotic interactions, such as predation, competition and facilitation seems to be the main drivers of diversity (Menge \& Sutherland 1976, Menge \& Olson 1990, Hewitt et al. 2005, Wiens 2011, Wisz et al. 2012). Although macroscale investigations on species diversity have been recognized as of major importance in a changing world (e.g. climate change: Brown et al. 2000, Harley et al. 2006; bioinvasion: Molnar et al. 2008), understanding how diversity is shaped in smaller scales may contribute to its maintenance, but is still poorly explored.

Rocky shores are dynamic coastal habitats under periodically tidal variation, and represent a transition zone between terrestrial and marine environments, which are under contrasting physical conditions (Ewel et al. 2001, Wall et al. 2001). As a result, organisms are distributed across the shore in horizontal bands according to its resistance to air exposure and competitive ability (Stephenson \& Stephenson 1972, Chappuis et al. 2014). However, studies looking at the processes affecting the diversity of benthic communities in the intertidal zone showed that besides the well-known drivers of zonation, variation in biological interactions and habitat heterogeneity at a scale of few centimeters or meters may play also an important role in the patterns of diversity (McGuinness \& Underwood 1986, Shurin \& Allen 2001, Fraschetti et al. 2005, Le Hir \& Hily 2005, Gingold et al. 2010, Valdivia et al. 2014).

A wide array of organisms acting as secondary substrate inhabit the rocky intertidal and this mosaic of hosts may help increasing diversity locally, since communities may change among the different hosts in a scale of a few meters (e.g. Parker et al. 2001, Kelly et al. 2008). Intertidal macroalgae are among the most abundant and diverse secondary substrate in rocky shores. They vary in color and shape, range from subtidal areas to the upper midlittoral, and can harbor diverse assemblages, providing both shelter and food for the associated fauna (Christie et al. 2009). The tridimensional complexity may create micro-habitats that protect associated organisms against predators (Duffy \& Hay 1991), wave action (Sotka 2007) and desiccation (Davenport et al. 1999), and may also trap sediments (Airold \& Virgilio 1998), which may favor deposit feeder species (Prathep et al. 2003). Besides, the alga itself and the epiphytic assemblage supported by it may be used as food by associated animals (Viejo 1999), and differences in diet preferences and algal palatability may favor different faunas (Duffy \& Hay 1991, Zamzow et al. 2010, Tavares et al. 2013, Machado et al. 2017). Thus, variation in both algal host attributes, and associated fauna needs in terms of habitat and food, results on species-specific interactions and, consequently, on a taxonomic diversity of associated organisms among coexisting macroalgae in the shore (Engelen et al. 2013, Best et al. 2014). In this way, the spatial heterogeneity of hosts and the algal identity may play a crucial role in maintaining the biodiversity in intertidal areas, reinforcing the idea that conservation efforts should take into account different spatial scales (Thompson et al. 2002).

Coastal areas are among the ecosystems deeply affected by human activity, since most of the world's population inhabits coastlines (Dafforn et al. 2015). The introduction of man-made structures, such as harbors, piers, marinas and breakwaters (Bulleri \& Chapman 2010, Mineur et al. 2012), and also the increased discharge of pollutants (Addison et al. 2008, Piola et al. 2009) are leading to a severe modification of coastal ecosystem functioning, mainly resulting in a loss of biodiversity (Airoldi et al. 2008, Magurran et al. 2015, Bianchelli et al. 2016). The Araçá Bay in the São Sebastião Chanel, São Paulo - Brazil, is an area under intense anthropogenic influence as a result of São Sebastião Harbor proximity, which leads to frequent sewage discharges and oil spills for decades. However, the area still holds a high biodiversity and has socio-economic importance for the local fisherman community that conduct artisanal fishery and shellfish harvesting in the area (Amaral et al. 2010). Recently, the Araçá Bay system has being threatened by the plan of expansion of São Sebastião Harbor (for details check Pardal-Souza et al. 2017), which would lead to irreversible damages to this ecosystem. Although the plan consists in covering the bay with suspended platforms, a recent study conducted in the area has shown that the limitation of light imposed by the platforms may lead to significant changes in the structure of sessile and mobile community, reducing the occurrence of macroalgae (Pardal-Souza et al. 2017).

Since heterogeneous micro-habitats can sustain a variable community, our goal was to verify if coexisting macroalgal hosts support different communities, contributing to the maintenance of biodiversity in the Araçá Bay. We selected three distinct macroalgae occurring at the same zone in the shore and compared the associated community to understand the importance of the algal identity on setting the patterns of diversity of associated fauna. We expected to find distinct patterns of abundance of organisms, richness, evenness and diversity of groups, and community structures among hosts, reinforcing the idea that heterogeneity at small scales may help maintaining biodiversity in intertidal systems.

\section{Material and Methods}

\section{Study Area}

Sampling was conducted in the rocky shores of Pernambuco Island (2348'54.9'S, 4524'24.6”W), inside the Araçá Bay in the São Sebastião Chanel, São Paulo - Brazil (for details check Amaral et al. 2010, Dias et al. in press). The Araçá Bay is a shallow bay that includes sandy and rocky shores, mud flats and mangroves (Dias et al. in press), sustaining a high biodiversity (Amaral et al. 2010). The rocky shore is composed by both platforms and variable sized boulders, which creates a heterogeneous and complex habitat (Amaral et al. 2016).

\section{Sampling Procedure}

To evaluate how the identity of co-occurring macroalgae can affect the associated fauna living on it, we selected three distinct algae: Ulva lactuca (Linnaeus 1753) - an ephemeral green alga with poorly branched foliose 
fronds; Bostrychietum community - a group of red algae with heavily branched fronds, dominated by Bostrychia sp. (Montagne 1842) and that normally occurs on the upper portions of the intertidal zone (García et al. 2016); algal turf - dominated by the red filamentous algae Gracilaria sp. (Greville 1830) that mostly occurs in the intertidal fringe.

The samples consisted of 30 cores (10 for each alga) with an area of $36 \mathrm{~cm}^{2}$ scraped along $20 \mathrm{~m}$ of a uniform rocky shore during a spring tide in July 2013. Bostrychietum beds extend from the supralittoral to the midlittoral while Ulva and turf beds extends from the midlittoral to the sublittoral fringe, so any difference in the associated fauna could be the result of habitat-specific traits or caused by the height of the algae on the shore. Because we were interested in the differences among associated fauna caused by the identity and the complexity created by secondary substrata, and not by differences in shore height, all samples were randomly collected in the midlittoral, where species distributions overlapped. Scraped samples were individually kept in alcohol $70 \%$ and then, in the laboratory, all organisms were separated and classified in major taxonomic groups. After separating the organisms, we quantified the volume of each sample in order to standardize the variables measured; however, since the volume did not differ among the three different algae $\left(\mathrm{F}_{2,27}=1.60 ; p=0.221\right)$, we decided to use the raw data, with no volume standardization.

\section{Data Analyses}

We compared the richness of taxonomic groups, evenness, Shannon diversity and total abundance of organisms with one-way ANOVA considering alga identity as a fixed factor. In order to achieve normality and homoscedasticity, abundance data was log transformed. For significant effects, we performed Tukey's test a posteriori for pairwise comparisons. Additionally, we performed separate analysis comparing the abundance of the most abundant groups among the algal species using the same ANOVA model.
To evaluate how the algal identity affects the structure of the associated fauna community, we used the abundances of all taxonomic groups in a multivariate approach, building a resemblance matrix using Bray-Curtis distance. The resemblance matrix was used in a PERMANOVA test with 999 unrestricted permutations of the raw data (Anderson 2001) using the same model explained above, and to build an n-MDS plot to better visualize groups relationship (Clark 1993). For significant factors, we performed a pairwise comparison (Anderson 2001) and then a SIMPER test to obtain the groups that most contributed to such significant effects (Clark 1993).

\section{Results}

We recorded 13,689 individuals of the following taxonomic groups: Amphipoda, Tanaidacea, Isopoda, Ostracoda, Cirripedia, Copepoda, Bivalvia, Gastropoda, Hydrozoa, Polychaeta, Oligochaeta, Nematoda, Rhabditophora, Ascidiacea, Bryozoa, Acari, Pycnogonida, Collembola, Diptera, Coleoptera and Lepidoptera. Amphipoda was the most abundant group, with $135 \pm 43$ individuals per sample, followed by Bivalvia, with $85 \pm 18$ individuals per sample, and Acari, with $60 \pm 22$ individuals per sample.

Algal identity did not affect richness of groups, evenness and Shannon diversity, but influenced total abundance, with more individuals being observed on turf and Bostrychietum when compared to Ulva (Figure 1, Table 1). Each algal species also showed a specific community structure for the associated fauna, clustering separately in the n-MDS plot (Figure 2, Table 1). The groups that most contributed to the differences among algal species were Amphipoda, Tanaidacea, Oligochaeta and Polychaeta, more abundant on turf; Isopoda, more abundant on turf and Ulva; Nematoda, with similar abundance on the three algae; Bivalvia, more abundant on turf and Bostrychietum; and Acari and Diptera, more abundant on Bostrychietum (Figure 3, Table 2 and 3).
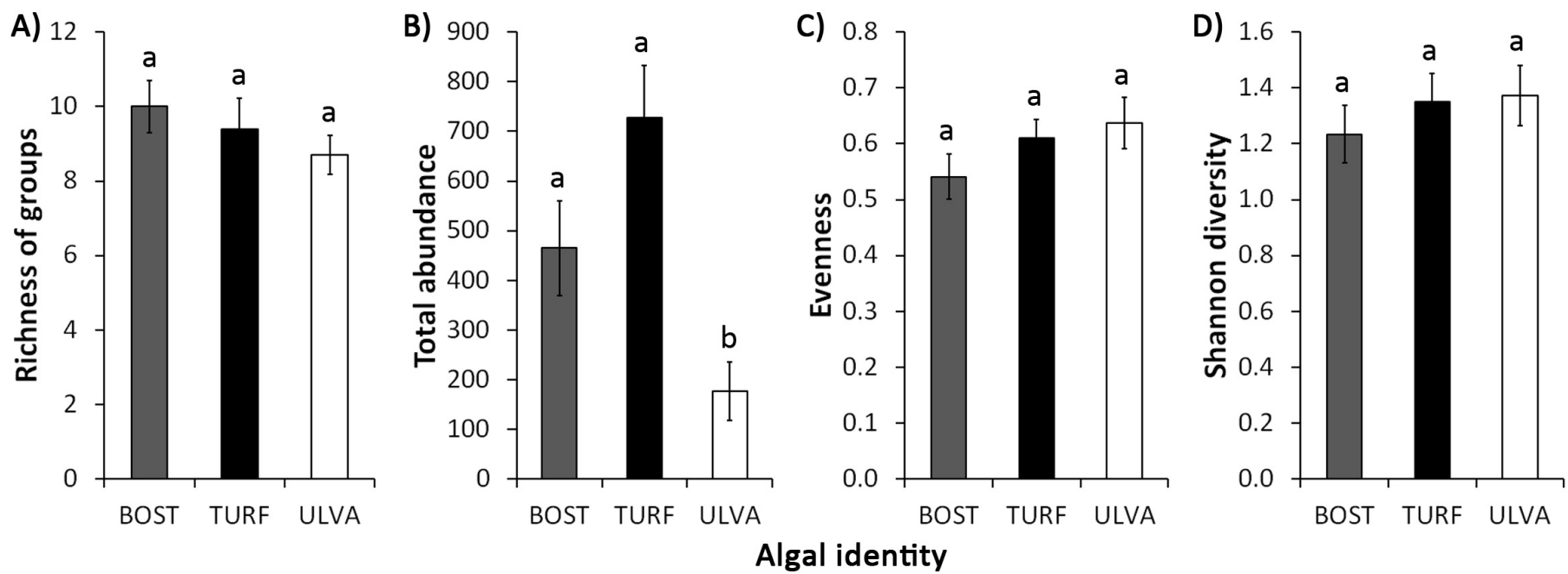

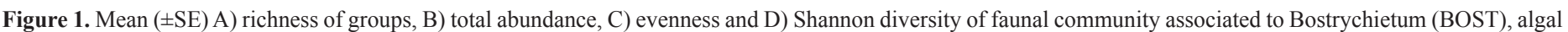

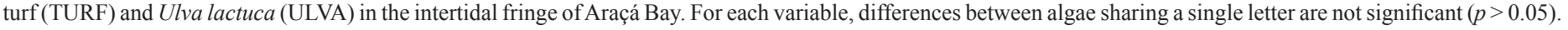

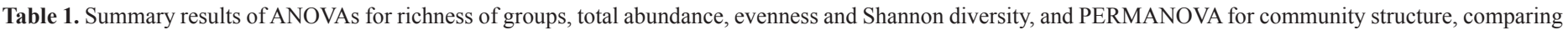
these attributes of associated fauna among Bostrychietum, algal turf and Ulva lactuca. 'ns' - non-significant; '***' $-p<0.001$.

\begin{tabular}{|c|c|c|c|c|c|c|c|c|c|c|c|c|c|c|c|c|}
\hline \multirow{2}{*}{ Source } & \multicolumn{4}{|c|}{ Richness of Groups } & \multicolumn{3}{|c|}{ Total Abundance } & \multicolumn{3}{|c|}{ Evenness } & \multicolumn{3}{|c|}{ Shannon Diversity } & \multicolumn{3}{|c|}{ Community Structure } \\
\hline & $D F$ & $M S$ & $F$ & $P$ & $M S$ & $F$ & $P$ & $M S$ & $F$ & $P$ & $M S$ & $F$ & $P$ & $M S$ & Pseudo-F & $P$ \\
\hline Algal Identity & 2 & 4.23 & 0.89 & ns & 6.25 & 13.8 & $* * *$ & 0.024 & 1.5 & ns & 0.055 & 0.5 & ns & 8733 & 12.6 & $* * *$ \\
\hline Error & 27 & 4.76 & & & 0.45 & & & 0.016 & & & 0.107 & & & 695 & & \\
\hline
\end{tabular}




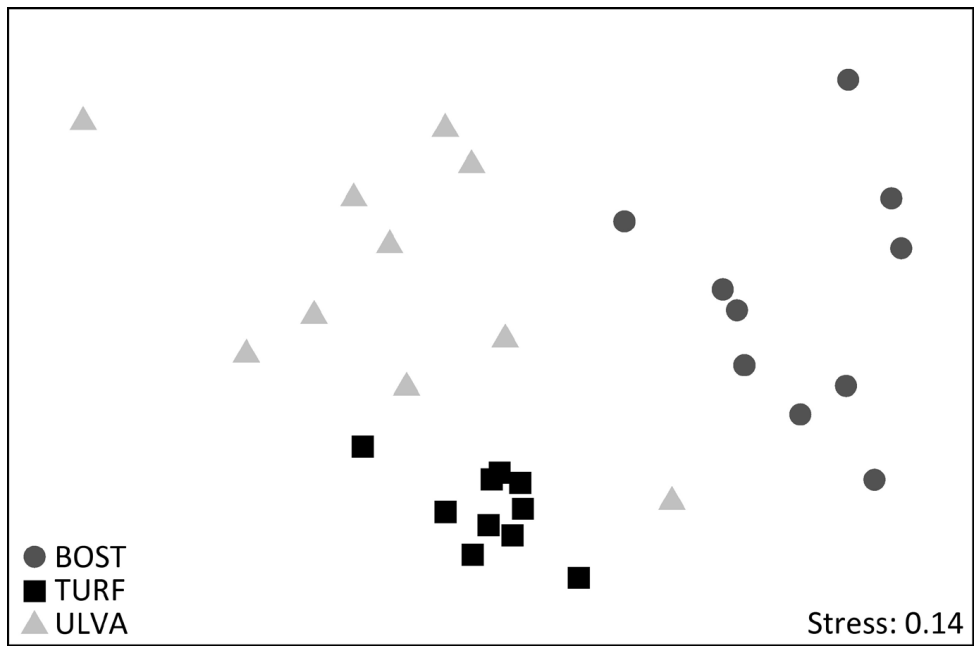

Figure 2. nMDS plot of abundance of all taxonomic groups of faunal communities associated to Bostrychietum (BOST - dark gray circles), algal turf (TURF - black squares) and Ulva lactuca (ULVA - light gray triangles) in the intertidal fringe of Araçá Bay.
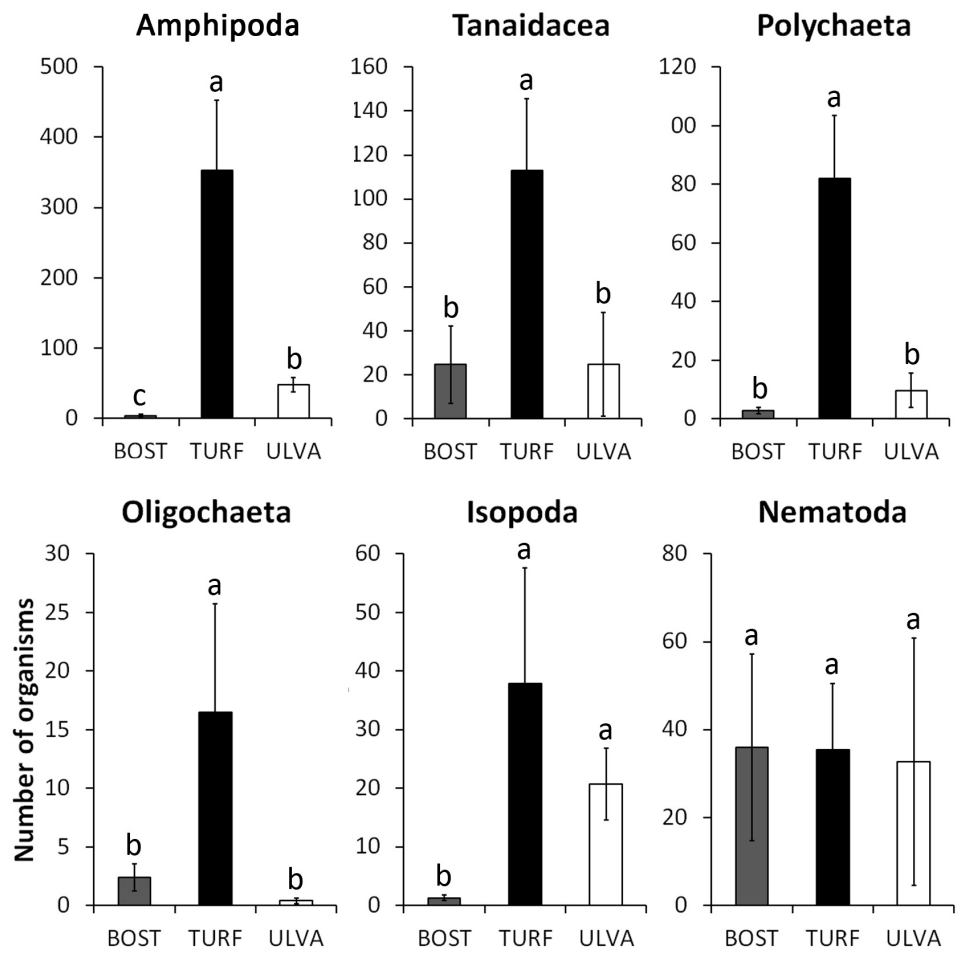

\section{Bivalvia}
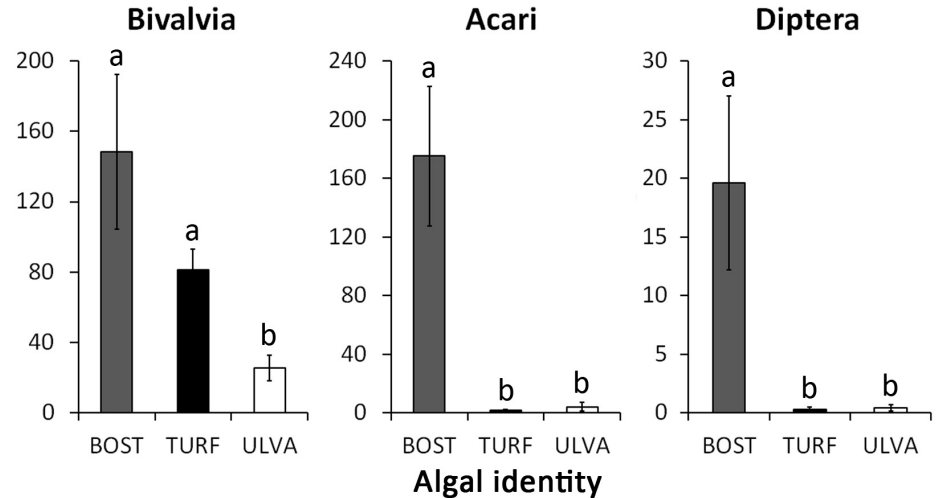

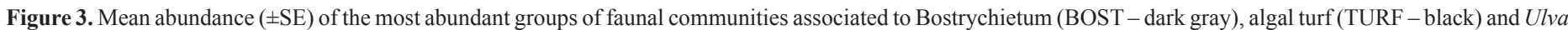

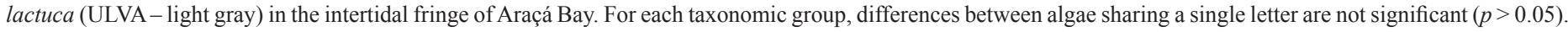


Algal host affects epifauna in a threatened bay

Table 2. SIMPER results showing the relative contribution (\%) of the five taxonomic groups that most contributed to significant differences among associated fauna of Bostrychietum (B), algal turf (T) and Ulva lactuca (U). Abbreviations in front of each taxa stand for the alga in which the group was more abundant.

\begin{tabular}{|c|c|c|c|c|c|}
\hline \multicolumn{2}{|c|}{$B \times T$} & \multicolumn{2}{|c|}{$B \times U$} & \multicolumn{2}{|c|}{$T x U$} \\
\hline Group & (\%) & Group & (\%) & Group & (\%) \\
\hline Amphipoda (T) & 15.16 & Acari (B) & 16.61 & Tanaidacea $(\mathrm{T})$ & 17.48 \\
\hline Acari (B) & 14.95 & Amphipoda (U) & 11.70 & Polychaeta (T) & 12.55 \\
\hline Polychaeta (T) & 11.43 & Diptera (B) & 8.62 & Nematoda $(\mathrm{T})$ & 9.66 \\
\hline Tanaidacea $(\mathrm{T})$ & 10.34 & Bivalvia (B) & 8.41 & Amphipoda $(\mathrm{T})$ & 8.75 \\
\hline Diptera (B) & 7.62 & Isopoda (U) & 8.26 & Oligochaeta $(\mathrm{T})$ & 8.42 \\
\hline
\end{tabular}

Table 3. Summary results of ANOVAs comparing the abundance of the most abundant groups of associated fauna among Bostrychietum, algal turf and Ulva lactuca. 'ns' - non-significant; '**' $-p<0.01 ;$ ' $* * *$ ' $-p<0.001$.

\begin{tabular}{|c|c|c|c|c|c|c|c|c|c|c|}
\hline \multirow{2}{*}{ Source } & \multicolumn{4}{|c|}{ Amphipoda } & \multicolumn{3}{|c|}{ Tanaidacea } & \multicolumn{3}{|c|}{ Isopoda } \\
\hline & $D F$ & $M S$ & $F$ & $P$ & $M S$ & $F$ & $P$ & $M S$ & $F$ & $P$ \\
\hline Algal Identity & 2 & 8.87 & 35.8 & $* * *$ & 5.77 & 12.98 & $* * *$ & 2.19 & 7.13 & $* *$ \\
\hline Error & 27 & 0.25 & & & 0.45 & & & 0.31 & & \\
\hline \multirow{2}{*}{ Source } & \multicolumn{4}{|c|}{ Oligochaeta } & \multicolumn{3}{|c|}{ Polychaeta } & \multicolumn{3}{|c|}{ Nematoda } \\
\hline & $D F$ & $M S$ & $F$ & $P$ & $M S$ & $F$ & $P$ & $M S$ & $F$ & $P$ \\
\hline Algal Identity & 2 & 1.49 & 7.50 & $* *$ & 5.48 & 26.90 & $* * *$ & 0.74 & 1.57 & $\mathrm{~ns}$ \\
\hline Error & 27 & 0.20 & & & 0.20 & & & 0.47 & & \\
\hline \multirow{2}{*}{ Source } & \multicolumn{4}{|c|}{ Bivalvia } & \multicolumn{3}{|c|}{ Acari } & \multicolumn{3}{|c|}{ Diptera } \\
\hline & $D F$ & $M S$ & $F$ & $P$ & $M S$ & $F$ & $P$ & $M S$ & $F$ & $P$ \\
\hline Algal Identity & 2 & 1.83 & 10.06 & $* * *$ & 10.30 & 54.80 & **** & 2.91 & 21.55 & $* * *$ \\
\hline Error & 27 & 0.18 & & & 0.19 & & & 0.14 & & \\
\hline
\end{tabular}

\section{Discussion}

We show that even under similar abiotic pressure (same rocky shore height), different coexisting algae influenced the fauna associated to them. Although we did not observe the effect of algal identity on all community metrics, the abundance of organisms and the community structure were particular for each algal host, showing a strong taxon-specificity between host and associated fauna, in a way that the coexisting algae increase the turnover and total diversity of animals in the Araçá Bay. Besides, more complex algae (Bostrychietum and turf) sustained higher abundances, reinforcing the idea that complexity creates an array of micro-habitats in different scales that supports more individuals.

Habitat complexity has been recognized as of major importance on characterizing the spatial distribution of species from intertidal areas (Beck 1998, 2000). Complex substrates are expected to provide several resources, allowing the maintenance of more abundant and diverse assemblages with different survival requirements (e.g. Hicks 1977). Within the macroalgae, higher branching can support higher faunal abundances by supplying additional surface for attachment (Hacker \& Steneck 1990) or by offering higher interstitial volume (Bueno et al. 2017). In our study, the highly branched turf and Bostrychietum hosted higher abundances of faunal groups, while the smooth sheet-like blades of Ulva supported less individuals, both accounting for the total as well as for the most abundant groups (Amphipoda, Bivalvia and Acari). The lower number of individuals on Ulva may be an effect of the reduced surface rugosity, demanding much effort for animals to keep anchored, as observed for amphipods (Hacker \& Steneck 1990). Besides, it does not provide as many refuges as intricate canopies (Zamzow et al. 2010), resulting in a very specific fauna inhabiting Ulva blades (Corte et al. 2012). Habitat selection on macroalgae can be size-dependent (Hacker and Steneck 1990), and the spaces between the overlapping blades of Ulva could be sufficient as shelter from predation for small, but not for large species (Holmlund et al. 1990).
The turf, mainly composed by Gracilaria in our study, hosted the highest abundances of most faunal groups, especially the peracarid crustaceans (Amphipoda, Tanaidacea and Isopoda) and annelids (Polychaeta and Oligochaeta). In shores from the Northwestern Atlantic Ocean, patches of Gracilaria vermiculophylla (Papenfuss 1967) are effective shelters for the amphipod Gammarus mucronatus (Say 1818) regarding both desiccation and predation risks (Wright et al. 2014). Turfs intricate canopy can retain water and ameliorate conditions during periods of air exposure (Bertness et al. 1999), enhancing the survivorship of G. mucronatus during low tides (Wright et al. 2014). During high tides, G. mucronatus on algal turf, similar to the studied here, were less prone to be detected by predators (Wright et al. 2014). We believe that such algal attributes would work for most of the groups found on the algal turf in Araçá Bay, representing then a suitable refuge from biotic and abiotic pressures.

Algae belonging to the Bostrychietum community are frequently found on upper intertidal areas on both rocky shores and mangroves. Since this region is under high abiotic stress (Connell 1972), it is expected that Bostrychietum species living in such region show adaptations to deal with emersion periods, as observed to Bostrcyhia radicans (Montagne 1842), which sustained maximum photosynthetic rates, constant respiratory rates and a fast recovery after relatively long periods of desiccation (Mann \& Steinke, 1988). Since the spatial distribution of macroalgae associated fauna can be related to host identity and vertical position on the shore (Bueno et al. 2017), faunal assemblages could develop a close relation with their host and occupy different levels on the shore. Mites (Acari), for example, use Bostrychietum as habitat and source of food and their spatial distribution on rocky shores is closely related to the host position (Pfingstl 2013). As previously observed for Bostrychietum covering mangrove pneumatophores in the same area (García et al. 2016), the rocky shore Bostrychietum in our study showed the presence of more resistant organisms like bivalves, acaris, and typically terrestrial animals, such as insects. The occurrence of these organisms in the lower limit of 
Bostrychietum bed in the midlittoral zone may reflect a close algal-fauna association and, in turn, a side-effect of insects using the algae as a proxy of the height in the shore.

While the turf and Bostrychietum are more perennial algae, Ulva is an ephemeral species that commonly increases the occurrence or abundance after nutrient input (Chávez-Sánchez et al. 2017, Dias et al. in press). The variation in abundance and occurrence of ephemeral algal species may contribute to promote temporal heterogeneity that was not explored here. The temporal variability of host coupled with the spatial heterogeneity imposed by perennial hosts may enhance diversity maintenance (Chesson 2000). Although we do not know if the differences of associated fauna composition observed among the three algal hosts sampled here will be maintained through time, the alternation between higher discrepancy and higher similarity among the associated fauna of different algal hosts will also impose temporal variation and does contribute to heterogeneity in such scale, maintaining diversity (Menge \& Sutherland 1976).

Benthic communities in the entrance of the Araçá Bay are more dynamic and controlled by oceanic processes operating at the São Sebastião Channel, while those at the inner portion of the bay are under the influence of Mãe Isabel River (Corte et al. 2017, Gorman et al. 2017, Dias et al. in press). As a consequence of this variable influence, the bay becomes shallower and richer in organic matter (Corte et al. 2017), and also receives a higher nitrogen input (Gorman et al. 2017) towards the inner portion. This environmental gradient spatially affects population dynamic of barnacles (Dias et al. in press) and also the community structure of sessile species in spatial and temporal scales (Kitazawa et al. in prep.). Here we show that the heterogeneity in the Araçá Bay is also observed in an even smaller scale, being mediated by the patchiness promoted by different algal hosts to the associated fauna. While the maintenance of such small-scale heterogeneity is important to guarantee refugees, acting as reservoirs to rare species (Hewitt et al. 2005, 2010), the maintenance of variation in a larger scale is also crucial, since local diversity does not depend solely on ecological processes, but is linked to the regional pool of species in marine communities, which highlights the importance of protecting larger areas (Witman et al. 2004) such as the Araçá Bay.

Our results corroborate the idea that community organization, in terms of abundance and community structure here, can vary in a considerable small-scale in the intertidal system (algal patches within the same rocky shore height) and, in our study, this is related to the heterogeneity promoted by different algal host holding specific associated faunas. Although we did not observe differences of richness, evenness and Shannon diversity, we believe that increasing the taxonomic resolution would result in differences in such metrics too. This is crucial to diversity maintenance not only in the local scale (among patches), but also in larger scales (regional diversity), with broad implications to conservation, especially today with the anthropogenic threat that most coastal systems have been facing, such as the Araçá Bay. The expansion of São Sebastião Harbor may lead not only to a homogenization of conditions, which may result on the survivor of only few resistant species, but will also preclude algae survivorship through light limitation caused by the suspended platforms (Pardal-Souza et al. 2017). As a consequence, following the decrease of diversity of macroalgae species, we may also expect a great loss of diversity of associated organisms, since they are closely related to their hosts.

\section{Acknowledgments}

HRF was supported by a grant from the PDPD/UFABC program. GMD has financial support from São Paulo Research Foundation (FAPESP 2016/17647-5). This work was supported by research funds granted by to Biota Araçá Project (FAPESP 2011/50317-5). We thank Felipe Oricchio, Felipe Dutra with field work and Centro de Biologia Marinha (CEBIMar-USP) for logistical support.

\section{Authors' Contributions}

HRF and GMD substantially contributed in the concept and design of the study and to data collection.

EAV, HRF and GMD contributed to data analysis and interpretation.

EAV, HRF, MB, FPPL and GMD contributed to manuscript preparation and critical revision, adding intellectual content.

\section{Conflicts of interest}

The authors declare that they have no conflict of interest related to the publication of this manuscript.

\section{References}

ADDISON, P.F.E., KNOTT, N.A. \& KEOUGH, M.J. 2008. Spatially variable effects of copper on sessile invertebrates across a marina. J. Exp. Mar. Biol. Ecol. 364: 19-23.

AIROLDI, L., BALATA, D. \& BECK, M.W. 2008. The Gray Zone: relationships between habitat loss an marine diversity and their applications in conservation. J. Exp. Mar. Biol. Ecol. 366: 8-15.

AIROLDI, L. \& VIRGILIO M. 1998. Responses of turf-forming algae to spatial variations in the deposition of sediments. Mar. Ecol. Prog. Ser. 165: 271-282.

AMARAL, A.C.Z., TURRA, A., CIOTTI, A.M., WONGTSCHOWSKI, C. \& SCHAEFFER-NOVELLI, Y. 2016. Vida na Baía do Araçá. Diversidade e importância. 2 ed. Editora Lume, São Paulo.

AMARAL, A.C.Z., MIGOTTO, A.E., TURRA, A. \& SCHAEFFER-NOVELLI, Y. 2010. Araçá: biodiversity, impacts and threats. Biota Neotrop. 10: 219-264

ANDERSON, M.J. 2001. A new method for non-parametric multivariate analysis of variance. Austral Ecol. 26: 32-46.

BECK, M. W. 1998. Comparison of the measurement and effects of habitat structure on gastropods in rocky intertidal and mangrove habitats. Mar. Ecol. Prog. Ser. 169: $165-178$.

BECK, M. W. 2000. Separating the elements of habitat structure: independent effects of habitat complexity and structural components on rocky intertidal gastropods. J. Exp. Mar. Biol. Ecol. 249: 29-49.

BERTNESS, M.D., LEONARD, G.H., LEVINE, J.M., SCHMIDT, P.R. \& INGRAHAM, A.O. 1999. Testing the relative contribution of positive and negative interactions in rocky intertidal communities. Ecology 80: 2711-2726.

BEST, R. J., CHAUDOIN, A. L., BRACKEN, M. E. S., GRAHAM, M. H. \& STACHOWICZ, J. J. 2014. Plant-animal diversity relationships in a rocky intertidal system depend on invertebrate body size and algal cover. Ecology 95: 1308-1322.

BIANCHELli, S., BUSCHI, E., DANOVARO, R. \& PUSCEDDU, A. 2016. Biodiversity loss and turnover in alternative states in the Mediterranean Sea: a case study on meiofauna. Sci. Rep. doi: 10.1038/srep34544.

BROWN, J.H., MORGAN ERNST, S.K., PARODY, J.M. \& HASKELL, J.P. 2001. Regulation of diversity: maintenance of species richness in changing environments. Oecologia 126: 321-332.

BUENO, M., DIAS, G.M. \& LEITE, F.P.P. 2017. The importance of shore height and host identity for amphipod assemblages. Mar. Biol. Res. doi: $10.1080 / 17451000.2017 .1306650$.

BULLERI, F. \& CHAPMAN, M.G. 2010. The introduction of coastal infrastructure as a driver of changes in marine environments. J. App. Ecol. 47: 26-35.

CHAPPUIS, E., TERRADAS, M., CEFALÌ, M.E., MARIANI, S. \& BALLESTEROS, E. 2014. Vertical zonation is the main distribution pattern of littoral assemblages on rocky shores at a regional scale. Estuar. Coast. Shelf. S. 147: 113-122.

CHÁVEZ-SÁNCHEZ, T., PIÑÓN-GIMATE, A., SERVIERE-ZARAGOZA, E., SÁNCHEZ-GONZÁLES, A., HERNÁNDEZ-CARMONA, G. \& CASASVALDEZ, M. 2017. Recruitment in Ulva blooms in relation to temperature, salinity and nutrients in a subtropical bay of the Gulf of California. Bot. Mar 60: $257-270$.

CHESSON, P. 2000. Mechanisms of maintenance of species diversity. Annu.1 Rev. Ecol. Syst. 31: 343-66. 
CHRISTIE, H., NORDERHAUG, K. M. \& FREDRIKSEN, S. 2009. Macrophytes as habitat for fauna. Mar. Ecol. Prog. Ser. 396: 221-234.

CLARKE, K.R. 1993. Non-parametric multivariate analyses of changes in community structure. Aust. J. Ecol. 18: 117-143.

CONNELL, J.H. 1972. Community interactions on marine rocky intertidal shores. Annu. Rev. Ecol. Syst. 3:169-192.

CORTE, G.N., NASCIMENTO M.C., PAVANI, L. \& LEITE, F.P.P. 2012. Crustacean species associated with Ulva spp. on beaches with different environmental characteristics. Bioikos 26: 101-111.

CORTE, G.N., CHECON, H.H., FONSECA, G., VIEIRA, D.C., GALLUCCI, F., DI DOMENICO, M. \& AMARAL, A.C.Z. 2017. Cross-taxon congruence in benthic communities: searching for surrogates in marine sediments. Ecol. Indic. 78:173-182.

DAFFORN, K., GLASBY, T., AIROLDI, L., RIVERO, N., MAYER-PINTO, M. \& JOHNSTON, E. 2015. Marine urbanization: an ecological framework for designing multifunctional artificial structure. Front. Ecol. Environ. 13: 82-90.

DAVENPORT, J., BUTLER, A. \& CHESHIRE, A. 1999. Epifaunal composition and fractal dimensions of marine plants in relation to emersion. J. Mar. Biol. Assoc. UK 79: 351-355.

DIAS, G.M., CHRISTOFOLETTI, R.A., KITAZAWA, K. \& JENKINS, S. Environmental heterogeneity at small spatial scales affects population and community dynamics on intertidal rocky shores of a threatened bay system. Ocean Coast. Manage. in press.

DUFFY J.E. \& HAY M.E. 1991. Food and shelter as determinantsof food choice by an herbivorous marine amphipod. Ecology 72: 1286-1298.

ELAHI, R., O'CONNOR, M.I., BYRNES, J.E.K., DUNIC, J., ERIKSSON, B.K., HENSEL, M.J.S. \& KEARNS, P.J. 2015. Recent trends in local-scale marine biodiversity reflect community structure and human impacts. Curr. Biol. 25: 1938-1943.

ENGELEN, A., PRIMO, A.L., CRUZ, T. \& SANTOS, R. 2013. Faunal differences between the invasive brown macroalga Sargassum muticum and competing native macroalgae. Biol. Invasions 15: 171-183.

EWEL, K., CRESSA, C., KNEIB, R., LAKE, P., LEVIN, L., PALMER, M., SNELGROVE, P. \& WALL, D. 2001. Managing critical transition zones. Ecosystems 4:452-460.

FRASCHETTI, S., TERLIZZI, A. \& BENEDETTI-CECCHI, L. 2005. Patterns of distribution of marine assemblages from rocky shores: evidence of relevant scales of variation. Mar. Ecol. Prog. Ser. 296: 13-29.

GARCÍA, A.B., BUENO, M. \& LEITE, F.P.P. 2016. The Bostrychietum community of pneumatophores in Araçá Bay: an analysis of the diversity of macrofauna. J. Mar. Biol. Assoc. UK 96: 1617-1624.

GINGOLD, R., MUNDO-OCAMPO, M., HOLOVACHOV, O. \& ROCHA-OLIVARES, A. 2010. The role of habitat heterogeneity in structuring the community of intertidal free-living marine nematodes. Mar. Biol. 157: 1741-1753.

GORMAN, D., TURRA, A., CONNOLLY, R.M., OLDS, A.D. \& SCHLACHER, T.A. 2017. Monitoring nitrogen pollution in seasonally-pulsed coastal waters requires judicious choice of indicator species. Mar. Pollut. Bull. 122: 1-2.

HACKER, S.D. \& STENECK, R.S. 1990. Habitat architecture and the abundance and body-size-dependent habitat selection of a phytal amphipod. Ecology 71: 2269-2285.

HARLEY, C.D.G., RANDALL HUGHES, A., HULTGREN, K.M., MINER, B.G., SORTE, C.J.B., THORNBER, C.S., RODRIGUEZ, L.F., TOMANEK.L. \& WILLIAMS, S.L. 2006. The impacts of climate change in coastal marine systems. Ecol. Lett. 9: 228-241.

HAWKINS, B.A., FIELD, R., CORNELL, H.V., CURRIE, D.J., GUÉGAN, J., KAUFMAN, D.M., KERR, J.T., MITTELBACH, G.G., OBERDORFF, T., O'BRIEN, E.M., PORTER, E.E. \& TURNER, J.R.G. 2003. Energy, water, and broad-scale geographic patterns of species richness. Ecology 84: 3105-3117.

HEWITT, J., THRUSH, S., LOHRER, A. \& TOWNSEND, M. 2010. A latent threat to biodiversity: consequences of small-scale heterogeneity loss. Biodiversity Conservation 19: 1315-1323.

HEWITT, J.E., THRUSH, S.F., HALLIDAY, J. \& DUFFY, C. 2005. The importance of small-scale habitat structure for maintaining beta diversity. Ecology 86: 1619-1626.
HICKS, G.R.F. 1977. Species associations and seasonal population densities of marine phytal harpacticoid copepods from Cook Strait. New Zeal. J. Mar. Fresh. 11: 621-643.

HOLMLUND, M.B., PETERSON, C.H. \& HAY, M.E. 1990. Does algal morphology affect amphipod susceptibility to fish predation? J. Exp. Mar. Biol. Ecol. 139: $65-83$.

HUSTON, M.A. 1999. Local processes and regional patterns: appropriate scales for understanding variation in the diversity of plants and animals. Oikos 86: 393-401.

KELLY, J.R., PROCTOR, H. \& VOLPE, J.P. 2008. Intertidal community structure differs significantly between substrates dominated by native eelgrass (Zostera marina L.) and adjacent to the introduced oyster Crassostrea gigas (Thunberg) in British Columbia, Canada. Hydrobiologia 596: 57-66.

LE HIR, M. \& HILY, C. 2005. Macrofaunal diversity and habitat structure in intertidal boulder fields. Biodiversity and Conservation, 14: 233-250.

MACHADO, G.B.O., SIQUEIRA, S.G.L. \& LEITE, F.P.P. 2017. Abundance, performance, and feeding preference of herbivorous amphipods associated with a host alga-epiphyte system. J. Exp. Mar. Biol. Ecol. 486: 328-335.

MAGURRAN, A.E., DORNELAS, M., MOYES, F., GOTELLI, N.J. \& MCGILL, B. 2015. Rapid biotic homogenization of marine fish assemblages. Nat. Commun. doi: $10.1038 /$ ncomms 9405 .

MANN, F. D. \& STEINKE, T.D. 1988. Photosynthetic and respiratory responses of the mangrove-associated red algae, Bostrychia radicans and Caloglossa leprieurii. S. Afr. J. Bot. 54: 203-207.

MCGUINNESS, K. \& UNDERWOOD, A. 1986. Habitat structure and the nature of communities on intertidal boulders. J. Exp. Mar. Biol. Ecol. 104: 97-123.

MENGE, B.A. \& OLSON A.M. 1990. Role of scale and environmental factors in regulation of community structure. Trends Ecol. Evol. 5: 52-57.

MENGE, B.A. \& SUTHERLAND, J.P. 1976. Species diversity gradients: synthesis of the roles of predation, competition, and temporal heterogeneity. Am. Nat. 110: 351-369.

MINEUR, F., COOK, E.J., MINCHIN, D., BOHN, K., MACLEOD, A. \& MAGGS, C.A. 2012. Changing coasts: marine aliens and artificial structures. Oceanog. Mar. Biol. 50: 189-234.

MOLNAR, J.L., GAMBOA, R.L., REVENGA, C. \& SPALDING, M.D. 2008. Assessing the global threat of invasive species to marine biodiversity. Front. Ecol. Environ. 6: 485-492.

NAVARRETE, S., WIETERS, E., BROITMAN, B. \& CASTILLA, J. 2005. Scales of benthic-pelagic and the intensity of species interactions: from recruitment limitation to top-down control. P. Natl. Acad. Sci. USA 102:18046-18051.

PARDAL-SOUZA, A., DIAS, G., JENKINS, S., CIOTTI, A. \& CHRISTOFOLETTI, R. 2017. Shading impacts by coastal infrastructure on biological communities from subtropical rocky shores. J. App. Ecol. 54:826-835.

PARKER, J., DUFFY, J. \& ORTH, R. 2001. Plant species diversity and composition: Experimental effects on marine epifaunal assemblages. Mar. Ecol. Prog. Ser. 224: $55-67$

PFINGSTL, T. 2013. Habitat use, feeding and reproductive traits of rocky-shore intertidal mites from Bermuda (Oribatida: Fortuyniidae and Selenoribatidae). Acarologia 53: 369-382

PIOLA, R.F., DAFFORN, K.A. \& JOHNSTON, E.L. 2009. The influence of antifouling practices on marine invasions. Biofouling 25: 633-644.

PRATHEP, A., MARRS, R.H. \& NORTON T.A.2003. Spatial and temporal variations in sediment accumulation in an algal turf and their impact on associated fauna. Mar. Biol. 142: 381-390.

RICKLEFS, R.E. 1987. Community diversity: Relative roles of local and regional processes. Science 235: 167-171.

SHURIN, J.B. \& ALLEN, E.G. 2001. Effects of competition, predation, and dispersal on species richness at local and regional scales. Am. Nat. 158: 624-637.

SOTKA, E.E. 2007. Restricted host use by the herbivorous amphipod Peramphithoe tea is motivated by food quality and abiotic refuge. Mar. Biol. 151:1831-1838.

STEPHENSON, T.A. \& STEPHENSON, A. 1972. Life between Tidemarks on Rocky Shores. W.H. Freeman and Company, San Francisco.

TAVARES, M.R., GRANDE H. \& JACOBUCCI G.B. 2013. Habitat and food selection by herbivorous amphipods associated with macroalgal beds on the southeast coast of Brazil. Nauplius 21: 9-15. 
THOMPSON, R. C., CROWE, T. P. \& HAWKINS, S. J. 2002. Rocky intertidal communities: past environmental changes, present status and predictions for the next 25 years. Environ. Conserv. 29: 168191.

VALDIVIA, N., DÍAZ, M.J., HOLTHEUER, J., GARRIDO, I., HUOVINEN, P. \& GÓMEZ, I. 2014. Up, down, and all around: scale-dependent spatial variation in rocky-shore communities of Fildes Peninsula, King George island, Antartica. PLOS One 9: e100714.

VIEJO, RM. 1999. Mobile epifauna inhabiting the invasive Sargassum muticum and two local seaweeds in northern Spain. Aquat. Bot. 64: 131-149.

WALL D., PALMER M. \& SNELGROVE P. 2001. Biodiversity in critical transition zones between terrestrial, freshwater, and marine soils and sediments: Processes, linkages, and management implications. Ecosystems 4:418-420.

WHITTAKER, R.J., WILLIS, K.J. \& FIELD, R. 2001. Scale and species richness: towards a general, hierarchical theory of species diversity. J. Biogeogr. 28: 453-470.

WIENS, J.J. 2011. The niche, biogeography and species interactions. Philos. T. R. Soc. B 366: 2336-2350.

WISZ, M.S., POTTIER, J., KISSLING, W.D., PELLISSIER, L., LENOIR, J., DAMGAARD, C.F., DORMANN, C.F., FORCHHAMMER, M.C., GRYTNES, J., GUISAN, A.,HEIKKINEN, R.K., HOYE, T.T., KÜHN, I., LUOTO, M.,
MIORANO, L., NILSSON, M., NORMAND, S., ÖCKINGER, E., SCHMIDT, N.M., TERMANSEN, M., TIMMERMANN, A., WARDLE, D.A., AASTRUP, P. \& SVENNING, J. 2012. The role of biotic interactions in shaping distributions and realised assemblages of species: implications for species distribution modelling. Biol. Rev. doi: 10.1111/j.1469-185X.2012.002355.x.

WITMAN, J.D., ETTER, R.J. \& SMITH, F. 2004. The relationship between regional and local species diversity in marine benthic communities: A global perspective. P. Natl. Acad. Sci. USA 101: 15664-15669.

WRIGHT, J.T., BYERS, J.E., DEVORE, J.L. \& SOTKA, E.E. 2014. Engineering or food? Mechanisms of facilitation by a habitat forming invasive seaweed. Ecology 95: 2699-2706.

ZAMZOW, J.P., AMSLER, C.D., MCCLINTOCK, J.B., BAKER, B.J. 2010. Habitat choice and predator avoidance by Antarctic amphipods: the roles of algal chemistry and morphology. Mar. Ecol. Progr. Ser. 400:155-63.

Received: $16 / 10 / 2017$

Revised: 27/12/2017

Accepted: 29/12/2017

Published online: 01/02/2018 